Relations industrielles

Industrial Relations

\title{
William N. Cooke, Labor-Management Cooperation: New Partnerships or Going in Circles?
}

\section{Bernard Portis}

Volume 46, numéro 3, 1991

URI : https://id.erudit.org/iderudit/050704ar

DOI : https://doi.org/10.7202/050704ar

Aller au sommaire du numéro

Éditeur(s)

Département des relations industrielles de l'Université Laval

ISSN

0034-379X (imprimé)

1703-8138 (numérique)

Découvrir la revue

Citer ce compte rendu

Portis, B. (1991). Compte rendu de [William N. Cooke, Labor-Management Cooperation: New Partnerships or Going in Circles?]. Relations industrielles / Industrial Relations, 46(3), 666-667. https://doi.org/10.7202/050704ar

Tous droits réservés @ C Département des relations industrielles de l'Universite Laval, 1991
Ce document est protégé par la loi sur le droit d'auteur. L’utilisation des services d'Érudit (y compris la reproduction) est assujettie à sa politique d'utilisation que vous pouvez consulter en ligne.

https://apropos.erudit.org/fr/usagers/politique-dutilisation/ 
and controversial Ray Rogers. Local P-9 President Jim Guyette worked closely with Rogers in the effort to not only win the strike at the plant gates but also on the stage of national public opinion.

Hardy Green, a consultant for Corporate Campaigns Inc., held a unique position within the strike apparatus, with a vantage point from which he could observe the internal workings of the campaign, as well as its public manifestations. His narrative of the strike, therefore, although certainly not objective, is a remarkably valuable record of the struggle. His account provides an almost day-by-day rendering of the manner in which determined grass-roots leaders, backed up by equally redoubtable rank and filers, held out against overwhelming odds until the company, the International union and the local and state police apparatus compelled them to throw in the towel.

Green's narrative deals with a union cause that, like so many others of the 1980s, seems to have been almost foredoomed to failure. The struggles of men and women desperately trying to maintain human dignity against insurmountable odds, takes on, in Green's telling, an almost Homeric quality. To be sure no one was completely without $\sin$ in this struggle. But certainly most nearly blameless were the Hormel workers who gave their economic all, only to be permanently replaced by scabs and those of their brethren who crossed the line. Reading Green's gripping account at times reduces one to tears.

Norman LEDERER

Thaddeus Stevens State School of Technology

Labor-Management Cooperation, New Partnerships or Going in Circles?, by William N. Cooke, Kalamazoo, Michigan, W.E. Upjohn Institute, 1990, 198 p., ISBN 0-88099-100-3

Cooke has conducted a much needed study of cooperative labor-management programs in unionized manufacturing companies. The study is particularly useful for its theoretical framework and survey of union and management experience with cooperative programs.

The theoretical framework introduced concepts which were used in interpreting survey results. The theoretical framework was mainly concerned with power sharing. Both unions and management must give up "relative power options" which heighten conflict in order to achieve benefits of cooperative efforts.

The survey is based on a random sample of unionized manufacturing companies in the United States. Information comes from 194 companies and most of these companies were represented by questionnaire responses from the plant manager, the union president and a headquarters executive.

The findings were quite clear for a study of this size. Following the work of Kochan, Cooke divided the parent corporations into three groups according to union strategy, "unionavoidance", "cooperation", and "mixed". The study found that most of plants, whose parent corporation, favored cooperation with unions, had formalized labor-management programs and few of the union avoidance corporations had cooperative programs in their plants. Thus the occurrence of formal cooperative programs in plants was greatly influenced by corporate strategy.

The plant level programs were classified as team based (quality circles, work teams, QWL/EI, gainsharing, and ESOPs) and committee based (labor-management and productivity committees). Success of these programs was measured in terms of improvement in quality, 
productivity and supervision. Both plant managers and the union officials indicated that cooperative programs usually had modest improvements rather than large improvements. Large improvements were associated with considerable commitment to the program and effort, such as frequent meetings of problem solving teams.

The study also showed that union leaders took pride in cooperative programs run in their plants. Cooke argued that more must be done to enlist union effort in running these programs. The unions had as much concern with saving manufacturing plants as did the corporations.

The message for Canadians is quite clear in terms of what it takes to compete with American plants. Greater effort must be made to promote labor-management programs at the plant level. These local efforts need to be supported by corporate strategy, national and international unions and government agencies. This book is highly recommended to leadership in government, industry and unions in order to become more effective in supporting labormanagement cooperation in Canadian manufacturing plants.

Bernard PORTIS

\section{University of Western Ontario}

The Practice of Labour Relations: Third Edition, by David A. Peach and Paul Bergman, Scarborough, Ont., McGraw Hill Ryerson, 1990, 437 p., ISBN 0-07-549936-3

Peach and Bergman have produced an excellent volume that should be seriously considered as a supplementary text for both introductory and advanced university and college courses in Canadian Industrial Relations. The outstanding feature of this text is its thirty-seven realistic, focussed and well written cases (several of which have not appeared in previous editions). The cases are suitable for classroom discussion and for role playing exercises by students.

The Practice of Industrial Relations is divided into six chapters each dealing with the following areas: an introduction to labour relations; the history of industrial relations in Canada; the organizing challenge; the negotiation challenge; the grievance challenge; and managing in a dynamic labour relations environment. The cases are appended to the various chapters. To the authors credit the cases address both traditional industrial relations concerns as well as more topical issues. Thus the chapters on organizing, negotiations and grievance handling include a number of excellent cases. In addition the chapter on managing in a dynamic labour relations environment includes cases that deal with: incentive plans; pay equity; job enrichment; and employee participation programs.

The classroom teacher should find the concise Instructors Manual very useful. The Manual has important 'tips' on how to teach cases and offers key points concerning each case. The Manual is also helpful in explaining how to use the Cashford Container case as a negotiation simulation for students. The inclusion of a scoring mechanism to use in grading, however, would have made this case even more valuable.

The main drawback of the text is the lack of scholarly detail in the otherwise well written narrative. For example, more of the narrative could be devoted to such important areas as the impact of the Charter of Rights and Freedoms on industrial relations. Also, many of the references used in the book should be updated. Thus the example given of union-management collusion is cited out of a U.S. text published in 1960; surely more recent examples (and Canadian ones at that!) are available. 